\title{
Strategi Belajar Kognitif Sebagai Mediator Peran Motivasi Belajar terhadap Prestasi Belajar
}

\section{Cognitive Learning Strategy as a Mediator in the Role of Learning Motivation on Learning Achievement}

\author{
Asmadi Alsa ${ }^{1}$, Adi Putra Hidayatullah ${ }^{2}$, Agustina Hardianti ${ }^{3}$ \\ ${ }^{1,2,3}$ Fakultas Psikologi, Universitas Gadjah Mada
}

Submitted 28 December 2020 Accepted 1 March 2021 Published 28 May 2021

\begin{abstract}
This research aimed to examine the role of intrinsic learning motivation on statistics achievement with cognitive learning strategy as mediator. The participants of this research were 179 statistics class students at faculty of psychology from three universities in Yogyakarta. Data collection of intrinsic learning motivation, rehearsal learning strategy, elaboration learning strategy, and organization learning strategy, was done by using scales; whereas variable of statistics achievement was collected by documentation of statistics achievement test at mid-semester and last semester. Data were analyzed by Structural Equation Modeling (SEM) using software of Analysis of Moment Stucture (AMOS).The results of this research showed: 1) Theoretical model stating that cognitive learning stratgy mediates role intrinsic learning motivation toward statistics achievement is fit with data; 2) Intrinsic learning motivation, rehearsal learning strategy, and organization learning strategy affect statistics achievement, whereas elaboration learning strategy do not affect statistics achievement; 3) Cognitive learning strategy, including rehearsal learning strategy, elaboration learning strategy, and organization learning strategy don't function as mediator of role intrinsic learning motivation on statistcs achievement.
\end{abstract}

Keywords: cognitive learning strategy; intrinsic learning motivation

Abstrak. Penelitian ini bertujuan untuk menguji peran motivasi belajar intrinsik terhadap prestasi belajar statistika dengan mediator strategi belajar kognitif. Subjek penelitian 179 mahasiswa kelas statistika Fakultas Psikologi dari tiga universitas di Yogyakarta. Instrumen penelitian yang digunakan untuk mengukur variabel motivasi belajar intrinsik, strategi belajar rehearsal, strategi belajar elaborasi, dan strategi belajar organisasi adalah skala; sedangkan variabel prestasi belajar statistika diperoleh dari dokumentasi tes hasil belajar tengah semester (UTS) dan akhir semester (UAS). Data yang diperoleh, dianalisis dengan Structural Equation Modeling (SEM) menggunakan perangkat lunak Analysis of Moment Stucture (AMOS). Hasil penelitian adalah: 1) Model teoretis yang menyatakan bahwa strategi belajar kognitif memediasi peran motivasi belajar intrinsik terhadap prestasi belajar statistika, cocok atau sesuai dengan data; 2) Variabel motivasi belajar intrinsik, strategi belajar rehearsal, dan strategi belajar organisasi berperan positif terhadap prestasi belajar statistika, sedangkan strategi belajar elaborasi tidak berperan terhadap prestasi belajar statistika; 3) Strategi belajar kognitif, yang meliputi strategi belajar rehearsal, strategi belajar elaborasi, dan strategi belajar organisasi, tidak berfungsi sebagai mediator atas peran motivasi belajar intrinsik terhadap prestasi belajar statistika.

Kata kunci: motivasi belajar; strategi belajar kognitif; prestasi belajar 
Strategi belajar adalah cara yang dipakai dalam belajar untuk mencapai tujuan belajar. Alexander et al. (dalam De Boer et al., 2012) mengatakan bahwa strategi belajar merupakan bentuk pengetahuan prosedural. Artinya, strategi belajar merupakan pengetahuan tentang bagaimana cara-cara belajar untuk mencapai tujuan belajar. Selanjutnya mereka mengatakan bahwa antara pengetahuan, strategi belajar dan motivasi belajar saling memengaruhi. Pelajar yang sudah mengetahui lebih banyak tentang suatu mata pelajaran, maka ia akan mampu menggunakan strategi belajar yang lebih kompleks dalam mempelajari pelajaran tersebut. Seorang pelajar yang tidak mempunyai dasar pengetahuan yang berkaitan dengan suatu mata pelajaran yang akan dipelajari, maka ia harus belajar dulu pengetahuan yang mendasari (prior knowledge), sedangkan pelajar yang sudah memahami pengetahuan yang mendasari, maka ia akan mampu secara langsung (instan) menghubungkan pengetahuan baru yang sedang dipelajari dengan pengetahuan yang sudah dimiliki, sehingga ia memperoleh makna atas apa yang ia pelajari.

Alexander et al. (dalam De Boer et al., 2012) mencirikan strategi belajar sebagai purposeful, dalam arti bahwa secara sadar strategi belajar digunakan oleh pelajar untuk mencapai hasil belajar yang diinginkan. Pemakaian strategi belajar membawa konsekuensi pada proses belajar, yang dapat memudahkan siswa dalam belajar serta meningkatkan performansi belajar. Dengan perkataan lain strategi belajar merupakan variabel yang esensial bagi perkembangan akademik. Strategi belajar berbeda dengan keterampilan belajar. Keterampilan belajar dapat terjadi secara otomatis, sedangkan strategi belajar menuntut usaha secara sadar dari pelajar. Penerapan strategi belajar membuat pelajar mampu secara personal meregulasi perilaku dan lingkungannya, sama halnya dengan meregulasi fungsi metakognitif pada dirinya. Boekaerts (dalam De Boer et al., 2012) mengelompokkan empat kategori utama strategi belajar, yaitu strategi kognitif, strategi metakognitif, strategi kelola sumber daya, dan strategi motivasional; sedangkan Pintrich dan De Groot (1990) mengemukakan tiga strategi belajar, yaitu strategi belajar metakognitif, strategi belajar kognitif, dan strategi belajar mengelola sumber daya. Sudah banyak penelitian mengenai strategi belajar yang diidentifikasi sebagai cara-cara efektif untuk meningkatkan belajar selama belajar berlangsung (Lee, 2002), dan bahkan belakangan ini berbagai strategi belajar telah diteliti dan dikembangkan pada aktivitas belajar dalam konteks multimedia.

Penelitian ini memfokuskan pada strategi belajar kognitif, yang meliputi strategi belajar rehearsal (mengulang), elaborasi, dan organisasi materi pelajaran. Ketiga strategi belajar kognitif itu dipilih karena berdasar pengalaman peneliti sebagai pendidik, ketiga strategi belajar ini banyak dipakai oleh mahasiswa. Strategi belajar kognitif merupakan satu tipe strategi belajar yang digunakan untuk meraih kesuksesan belajar. Berbagai strategi belajar kognitif yang digunakan pelajar telah banyak diteliti, seperti rehearsal (mengulang), elaborasi, dan mengorganisasi bahan pelajaran (Zimmerman \& MartinezPons, 1990). Weinstein dan Mayer (dalam Wolters et al., 2003) mengatakan bahwa strategi kognitif menghafal atau menggunakan cara-cara tertentu untuk membantu ingatan 
merupakan strategi belajar yang juga banyak dilakukan pelajar, seperti memahami konsep dengan kata-kata sendiri, meringkas bahan, membuat skema, membuat jaringan, menyusun diagram, dan membuat catatan.

Prestasi belajar dipengaruhi oleh strategi belajar dan motivasi belajar, selain faktorfaktor determinan lainnya. Penelitian ini dilakukan pada mahasiswa Fakultas Psikologi dalam konteks belajar statistika; bertujuan untuk menguji peran motivasi belajar terhadap prestasi belajar statistika melalui mediator strategi belajar rehearsal, elaborasi, dan organisasi materi. Permasalahan penelitiannya adalah, apakah peran motivasi belajar terhadap prestasi belajar matematika pada mahasiswa psikologi dimediasi oleh strategi belajar rehearsal, elaborasi, dan organisasi?

Proses belajar merupakan hal yang sensitif dalam memfasilitasi aktivitas belajar pada mata pelajaran yang berbeda-beda. Motivasi dan strategi belajar kognitif merupakan komponen dari proses belajar, yang saling berhubungan satu sama lain dan yang memengaruhi prestasi belajar (Anais et al., 2012). Para ahli psikologi seperti Alexander et al. (dalam Slavin, 2012) mendefinisikan motivasi sebagai satu proses internal yang mengaktifkan, mengarahkan, dan mengawal perilaku untuk sampai pada suatu tujuan. Menurut Ormrod (2003) siswa yang memiliki motivasi belajar akan: 1) mengarahkan perilakunya ke arah tujuan tertentu, 2) meningkatkan usaha dan energi, dan 3) meningkatkan inisiasi dan persistensi (ketekunan) dalam belajar.

Motivasi ada dua macam yaitu motivasi intrinsik dan motivasi ekstrinsik. Motivasi belajar intrinsik terjadi apabila siswa belajar karena keinginannya sendiri untuk belajar sampai berhasil, tanpa memedulikan ada-tidaknya rewards eksternal apa pun, sedangkan motivasi belajar ekstrinsik adalah aktivitas belajar yang didasarkan pada faktor-faktor eksternal seperti rewards dan punishments (Parsons et al., 2001). Ormrod (2003) mengatakan bahwa siswa yang termotivasi secara intrinsik, keterlibatannya dalam suatu aktivitas disebabkan karena aktivitas tersebut memberikan kesenangan, membantu dirinya mengembangkan keterampilan yang mereka anggap penting, atau yang secara etik atau moral aktivitas tersebut baik untuk dilakukan. Peneliti berasumsi bahwa pelajar yang motivasi belajarnya intrinsik lebih banyak menggunakan strategi dalam belajar dibandingkan dengan pelajar yang motivasi belajarnya ekstrinsik. Karena alasan tersebut penelitian ini membatasi pada motivasi intrinsik sebagai salah satu variabel penelitian. Berdasar pendapat Ormord di atas peneliti mengidentifikasi dua indikator dalam motivasi belajar intrinsik, yaitu memiliki minat terhadap suatu pelajaran (belajar sebagai sarana pengembangan diri, secara etik dan moral belajar baik untuk dilakukan), dan memiliki rasa senang mempelajari mata pelajaran tersebut.

Seperti disebutkan bahwa terdapat tiga strategi belajar, yaitu strategi belajar kognitif, strategi belajar metakognitif, dan strategi mengelola sumber daya. Strategi belajar metakognitif adalah merencanakan belajar (planning), melakukan pemantauan dalam belajar (monitoring), dan melakukan evaluasi hasil belajar (evaluating). Strategi belajar kognitif meliputi mengulang mata pelajaran (rehearsal), melakukan elaborasi atas 
materi pelajaran yang dipelajari, dan mengorganisasi materi pelajaran sedemikian rupa agar mudah dipahami. Strategi mengelola sumber daya meliputi pengelolaan lingkungan dan waktu belajar, regulasi usaha, belajar kelompok, dan mencari bantuan belajar.

Strategi belajar kognitif, merentang dari strategi sederhana seperti menggunakan alat bantu untuk mengingat, sampai dengan strategi yang lebih canggih seperti dalam aktivitas membaca, belajar matematika, menulis, memecahkan masalah, dan penalaran (Wolters et al., 2003). Penelitian ini menggunakan tiga strategi belajar kognitif utama, yaitu strategi rehearsal, elaborasi, dan organisasi. Strategi rehearsal adalah cara menyimpan informasi dalam memori dengan mengulangi secara terus menerus materi yang dipelajari. Strategi elaborasi adalah cara memperoleh pengetahuan dengan menyusun hubungan-hubungan antara pengetahuan yang sudah dimiliki dengan materi yang dipelajari sekarang. Strategi organisasi adalah cara memperoleh pengetahuan dengan memvisualisasikan bahan (dalam bentuk gambar, grafik, dll.) untuk memudahkan belajar (De Boer et al., 2012). Menurut Wolters et al. (2003) strategi mengulang materi pelajaran (rehearsal) meliputi usaha memorisasi dengan mengulanginya secara terus menerus atau tipe pemrosesan informasi yang sifatnya dangkal seperti resitasi; strategi elaborasi merupakan suatu pendekatan belajar yang lebih dalam (deep learning), melalui usaha seperti meringkas bahan, menghafal pelajaran dengan menggunakan kata-kata atau kalimat sendiri; sedangkan strategi organisasi adalah mengorganisasi materi secara visual untuk memudahkan belajar.

Hasil-hasil penelitian yang mengaitkan antara variabel motivasi dan prestasi belajar, yang merupakan variabel-variabel dalam penelitian ini, sudah banyak dilakukan. Muhammad et al. (2013) melakukan penelitian berjudul Impact of motivation on student' academic performance. Responden penelitiannya sebanyak 114 laki-laki dan 104 perempuan mahasiswa Fakultas Studi Islam, Ilmu-ilmu Sosial, serta Ekonomi dan Manajemen Bisnis University Sultan Zainal Abidin Malaysia. Hasil penelitiannya menunjukkan adanya korelasi positif yang signifikan $(r=0,667)$ antara motivasi dan performansi akademik (indeks prestasi). Amrai et al. (2011) melakukan penelitian berjudul The relationship between academic motivation and academic achievement students. Subjek penelitiannya sebanyak 115 laki-laki dan 137 perempuan mahasiswa Universitas Teheran. Hasil penelitiannya menemukan adanya korelasi positif signifikan antara motivasi akademik dan prestasi akademik. Selanjutnya, Chow dan Yong (2013) melakukan penelitian bertajuk Secondary School Students' Motivation and Achievement in Combined Science. Sampel penelitiannya adalah 324 siswa (141 laki-lai dan 183 perempuan), yang berasal dari 8 SMA Negeri di Brunai Darussalam. Hasil penelitian menunjukkan bahwa ada korelasi yang positif antara motivasi belajar siswa dengan prestasi belajar IPA.

Penelitian yang mengaitkan antara variabel motivasi dan strategi belajar, dilakukan oleh Meniado (2016) pada 60 mahasiswa laki-laki jurusan Bahasa Inggris (EFL) di Universitas milik pemerintah Arab Saudi. Hasil penelitiannya adalah, adanya korelasi positif antara motivasi membaca dan strategi dalam belajar membaca bahasa asing. 
Selanjutnya, penelitian yang dilakukan Schmidt dan Watanabe (2001) terhadap 2.089 mahasiswa Universitas Hawaii yang belajar bahasa asing (Mandarin, Tagalog, Jepang, dan Prancis) menemukan bahwa motivasi belajar bahasa asing berkorelasi positif dengan strategi belajar.

Penelitian yang mengaitkan keterkaitan antara strategi belajar dengan prestasi belajar telah dilakukan oleh beberapa ahli. Ruffing et al. (2013) melakukan penelitian eksperimen quasi berjudul Learning strategies and general cognitive ability as predictors of gender-specific academic achievement. Subjek penelitiannya adalah 136 pelajar kelas tiga SD (64 subjek kelompok eksperimen, 62 subjek kelompok kontrol) di kota Lordegan. Hasil penelitiannya menunjukkan bahwa pembelajaran dengan menggunakan strategi kognitif mempunyai dampak positif terhadap performansi belajar mata pelajaran IPA. Akyol et al. (2010) dalam penelitiannya mengaitkan strategi belajar elaborasi, organisasi, dan strategi metakognitif dengan prestasi belajar IPA pada siswa kelas 1 SMP di Turki. Temuan penelitiannya menunjukkan bahwa penggunaan strategi belajar elaborasi, organisasi, dan regulasi metakognitif memberikan kontribusi yang signifikan terhadap prestasi belajar IPA. Mengapa siswa yang strategi belajarnya tinggi performansi akademiknya juga tinggi, menurut Chin dan Chin (2009) karena mereka adalah pemikir yang efektif, yang menggunakan lebih banyak strategi untuk membaca, menulis, memecahkan masalah, dan menalar. Para peneliti telah membandingkan antara sekolah-sekolah yang performansi siswanya tinggi dengan sekolah-sekolah yang performansi siswanya rendah (Langer dalam Chin \& Chin, 2009). Hasilnya menemukan bahwa sekolah-sekolah yang performansi siswanya tinggi, pengajarannya lebih banyak menitik- beratkan pada strategi belajar kognitif dibandingkan sekolah-sekolah yang performansi belajar siswanya rendah (Chin \& Chin, 2009). Tinajero et al. (2015) melakukan penelitian terhadap 124 laki-laki dan 189 perempuan mahasiswa Universitas Brazil dengan judul Cognitive style and learning strategies as factors which affect academic achievement of Brazilian university students. Hasil penelitiannya menemukan bahwa gaya dan strategi belajar kognitif secara signifikan berkontribusi terhadap prestasi akademik. Penelitian Anais et al. (2012) juga menemukan adanya korelasi positif signifikan antara strategi belajar kognitif dengan indeks prestasi semester pertama pada mahasiswa Fakultas Teknik Sipil Universitas Katolik di Chili.

Murayama dan Pekrun (2012) melakukan penelitian tentang perkembangan prestasi matematika mulai dari siswa kelas lima SD sampai dengan kelas satu SMA dengan judul Predicting Long-Term Growth in Students' Mathematics Achievement: The Unique Contributions of Motivation and Cognitive Strategies. Subjek penelitiannya sebanyak 3.530 siswa di Bavaria, Jerman, yang mengikuti Project for the Analysis of Learning and Achievement in Mathematics (PALMA). Penelitian ini bertujuan untuk menguji bagaimana motivasi, strategi belajar kognitif, dan inteligensi secara bersama-sama memprediksi perkembangan prestasi matematika siswa selama lima tahun. Hasilnya menunjukkan bahwa koefisien korelasi antara inteligensi dengan prestasi belajar matematika lebih tinggi dibandingkan dengan koefisien korelasi antara motivasi dengan prestasi matematika, serta antara 
strategi belajar dengan prestasi matematika. Namun temuan yang lebih menarik adalah, bahwa koefisien korelasi antara inteligensi dan prestasi belajar matematika cenderung stabil, sedangkan koefisien korelasi motivasi dan strategi belajar kognitif dengan prestasi belajar matematika semakin meningkat dari tahun pertama sampai dengan tahun kelima. Ini secara jelas menunjukkan pentingnya motivasi belajar dan strategi belajar kognitif dalam memfasilitasi perkembangan kompetensi matematika siswa.

Berdasar hasil-hasil penelitian yang diuraikan di atas ditemukan bahwa: Pertama, motivasi belajar berkorelasi positif dengan prestasi akademik (Amrai et al., 2011; Muhammad et al., 2013), berkorelasi positif dengan prestasi belajar IPA (Chow \& Yong, 2013), dan juga berkorelasi positif dengan prestasi belajar matematika (Murayama \& Pekrun, 2012). Kedua, motivasi belajar berkorelasi positif dengan strategi belajar kognitif (Schmidt \& Watanabe, 2001; Meniado, 2016). Ketiga, strategi belajar kognitif berkorelasi positif dengan penalaran dan pemecahan problem (Chin \& Chin, 2009); dengan prestasi akademik (Tinajero et al., 2015); dengan prestasi belajar ilmu pengetahuan alam (Akyol et al., 2010; Ruffing et al., 2013); dengan prestasi belajar matematika (Murayama \& Pekrun, 2012); dan dengan prestasi belajar semester pertama pada mahasiswa Fakultas Teknik Sipil Universitas Katolik di Chili (Anais et al., 2012).

Wolters (1998) mengatakan bahwa motivasi menyangkut proses yang terlibat dalam pemunculan awal suatu intensi, sedangkan untuk mempertahankan intensi sampai tujuan belajar tercapai diperlukan regulasi usaha. Model proses belajar yang dikemukakan oleh Biggs dan model motivasi belajar intrinsik yang dikemukakan oleh McCombs (Chung, 2000) berasumsi bahwa variabel motivasi merupakan variabel eksogen yang memengaruhi prestasi belajar tidak hanya secara langsung, tapi juga secara tidak langsung melalui variabel mediator strategi belajar metakognitif dan strategi belajar kognitif. Penelitian yang peneliti lakukan ini, berbeda dengan penelitian yang dilakukan oleh Bandalos et al. (2003) berjudul A model of statistics performance based on achievement goal theory. Walaupun sama-sama meneliti prestasi belajar statistika dan sama-sama menguji model teoretik. Penelitian yang peneliti lakukan ini didasarkan pada pendapat Wolter, model proses belajar dari Biggs, dan motivasi belajar intrinsik yang dikemukakan oleh McComb, serta diperkuat dengan hasil-hasil penelitian yang dikemukakan di atas. Tujuannya adalah untuk menguji secara empiris, apakah strategi belajar rehearsal, elaborasi, dan organisasi berperan sebagai mediator atas peran motivasi belajar terhadap prestasi belajar statistika. Oleh karena itu peneliti mengajukan hipotesis penelitian sebagai berikut: 1) Hipotesis utama penelitian adalah, strategi belajar rehearsal, elaborasi, dan organisasi memediasi peran motivasi belajar statistika terhadap prestasi belajar statistika sesuai dengan data; 2) Motivasi belajar statistika berperan positif terhadap strategi rehearsal; 3) Motivasi belajar statistika berperan positif terhadap strategi elaborasi; 4) Motivasi belajar statistika berperan positif terhadap strategi organisasi; 5) Strategi belajar rehearsal berperan positif terhadap prestasi belajar statistika; 6) Strategi belajar elaborasi berperan positif terhadap prestasi belajar statistika; 7) Strategi belajar 
organisasi berperan positif terhadap prestasi belajar statistika; 8) Motivasi belajar statistika berperan positif terhadap prestasi belajar statistika, baik secara langsung maupun dimediasi oleh strategi belajar kognitif.

\section{Metode}

Variabel-variabel yang dilibatkan dalam penelitian ini adalah: 1) Variabel Independen (sebagai variabel eksogen) adalah Motivasi belajar intrinsik; 2) Variabel endogen sebagai mediator adalah Strategi belajar kognitif (rehearsal, elaborasi, dan organisasi); serta 3) Variabel endogen sebagai variabel dependen adalah Prestasi Belajar Statistika.

Subjek penelitiannya adalah mahasiswa Fakultas Psikologi dari tiga universitas di Yogyakarta yang mengambil mata kuliah Statistika. Instrumen pengumpulan data yang digunakan adalah skala motivasi intrinsik belajar statistika, skala strategi belajar rehearsal, skala strategi belajar elaborasi, skala strategi belajar organisasi, dan tes hasil belajar dari ujian tengah semester dan ujian akhir semester. Jumlah butir untuk setiap skala sebanyak empat butir, relatif sedikit mengingat variabel yang diukur konstruksi teorinya tidak kompleks. Dalam proses menyusun butir dari keempat skala penelitian, setelah butirbutir ditulis selanjutnya dimintakan kepada lima mahasiswa peserta matakuliah statistika untuk dikonfirmasi bahwa isi dan bahasa dalam butir-butir tersebut dipahami.

Validitas isi (content validity) dipakai untuk keempat skala atau instrumen penelitian tersebut. Butir-butir skala motivasi belajar intrinsik disusun berdasar dua indikator, yaitu memiliki minat terhadap mata kuliah statistika, dan memiliki rasa senang mempelajari mata kuliah statistika. Untuk skala strategi belajar rehearsal, elaborasi, dan organisasi langsung dibuat butirnya masing-masing berdasar pengertian dari ketiganya. Butir untuk masing-masing skala penelitian disajikan pada Tabel 1. 
Tabel 1.

Butir-butir Motivasi Belajar Intrinsik, Strategi Rehearsal, Strategi Elaborasi, dan Strategi Organisasi.

\begin{tabular}{|c|c|}
\hline Variabel & Nomor dan Rumusan Butir \\
\hline Motivasi intrinsik & $\begin{array}{l}\text { 1. Saya bisa lebih fokus dan berkonsentrasi belajar statistika } \\
\text { dibanding dengan belajar mata kuliah yang lain. } \\
\text { 2. Sama sekali bukan merupakan beban bagi saya ketika } \\
\text { mendapat tugas atau mengerjakan PR mata kuliah statistika. } \\
\text { 3. Saya selalu tertarik mengikuti kuliah mata kuliah statistika. } \\
\text { 4. Saya lebih menyukai belajar mata kuliah statistika } \\
\text { dibandingkan dengan belajar mata kuliah lain. }\end{array}$ \\
\hline Strategi Rehearsal & $\begin{array}{l}\text { 1. Setelah mengikuti kuliah statistika di kelas, saya pelajari lagi } \\
\text { materi kuliah tersebut di rumah. } \\
\text { 2. Walaupun tidak ada PR statistika, saya seringkali mengerjakan } \\
\text { soal-soal statistika yang materinya sudah diajarkan di kelas. } \\
\text { 3. Bila saya belum paham materi pelajaran statistika, saya akan } \\
\text { mengulanginya sampai paham. } \\
\text { 4. Saya rutin mengulangi belajar mata kuliah statistika yang sudah } \\
\text { diajarkan di kelas. }\end{array}$ \\
\hline Strategi Elaborasi & $\begin{array}{l}\text { 1. Dalam belajar matematika, selain belajar dari yang diajarkan } \\
\text { dosen, saya juga belajar dari sumber yang lain. } \\
\text { 2. Untuk mengikuti mata kuliah statistika minggu depan } \\
\text { (selanjutnya), saya berusaha sudah menguasai materi kuliah } \\
\text { statistika yang diajarkan sebelumnya. } \\
\text { 3. Ketika saya tidak paham mengenai satu pokok bahasan dalam } \\
\text { belajar statistika, saya akan mempelajari pokok bahasan } \\
\text { sebelumnya yang berkaitan. } \\
\text { 4. Untuk memahami konsep dan teori dalam statistika, saya } \\
\text { mengapalkannya dengan menggunakan kata-kata sendiri. }\end{array}$ \\
\hline Strategi Organisasi & $\begin{array}{l}\text { 1. Dalam memahami satu konsep tentang statistika, biasanya saya } \\
\text { merumuskannya dengan kalimat atau bahasa saya sendiri, yang } \\
\text { penting esensinya tidak berbeda. } \\
\text { 2. Saya membuat catatan tentang garis besar dari materi pelajaran } \\
\text { statistika yang saya pelajari untuk mempermudah } \\
\text { memahaminya } \\
\text { 3. Pada buku catatan kuliah untuk mata kuliah statistika, saya beri } \\
\text { garis bawah, stabilo, atau tanda-tanda lain untuk memudahkan } \\
\text { saya dalam mempelajarinya. } \\
\text { 4. Untuk efisiensi dalam memahami materi pelajaran statistika, } \\
\text { saya menyusun materi sedemikian rupa (dalam bentuk tabel, }\end{array}$ \\
\hline
\end{tabular}


gambar, pola, narasi, maping, dsb.) agar saya lebih mudah memahaminya.

Keempat skala penelitian yang sudah disusun selanjutnya dilakukan uji coba. Dari hasil uji coba terhadap 117 mahasiswa psikologi ditemukan koefisien alpha dan daya beda butir untuk masing-masing skala disajikan pada Tabel 2.

Tabel 2.

Koefisien Alpha dan Daya Beda Butir Masing-masing Skala

\begin{tabular}{|c|c|c|c|c|}
\hline Skala & Koefisien Alpha & Daya 1 & da Butir & \\
\hline Motivasi Belajar & 0,801 & $\begin{array}{l}\text { MO1 }=0,606, \\
\text { MO4 }=0,684\end{array}$ & $\mathrm{MO} 2=0,569$, & MO3 $=0,601$, \\
\hline $\begin{array}{l}\text { Strategi Belajar } \\
\text { Rehearsal }\end{array}$ & 0,638 & $\begin{array}{l}\text { RE1=0,496, } \\
\text { RE4=0,453 }\end{array}$ & RE2=0,426, & RE3 $=0,314$, \\
\hline $\begin{array}{l}\text { Strategi Belajar } \\
\text { Elaborasi }\end{array}$ & 0,669 & $\begin{array}{l}\text { EL1=0,297, } \\
\text { EL4=0,463 }\end{array}$ & $\mathrm{EL} 2=0,520$, & EL3 $=0,551$, \\
\hline $\begin{array}{l}\text { Strategi Belajar } \\
\text { Organisasi }\end{array}$ & 0,614 & $\begin{array}{l}\text { OR1=0,382, } \\
\text { OR4=0,416 }\end{array}$ & OR2=0,380, & OR3=0,399, \\
\hline
\end{tabular}

Setelah keempat skala diestimasi validitas dan reliabilitasnya seperti diuraikan di atas, langkah selanjutnya adalah pengambilan data. Sebanyak 179 mahasiswa yang berasal dari tiga universitas diambil secara convenience (convenience sampling) sebagai sampel penelitian. Responden diminta mengisi keempat skala, masing-masing skala motivasi intrinsik belajar statistika, skala strategi rehearsal, skala strategi elaborasi, dan skala strategi organisasi. Data variabel prestasi belajar statistika diambil dari dokumentasi nilai final (gabungan nilai UTS dan UAS) mata kuliah statistika dari tiga universitas. Isi materi matematika yang diujikan sesuai dengan silabus yang terdapat di dalam kurikulum mata kuliah statistika, meliputi materi menghitung nilai rata-rata, median, desil, persentil, jenjang persentil, mean deviation, standard deviation, varian, dan nilai standar Z. Mengingat sampel penelitian berasal dari tiga perguruan tinggi, maka nilai hasil ujian statistika yang dipakai dalam analisis data adalah nilai standar Z. Artinya, nilai UTS dan UAS statistika untuk masing-masing kelas dari universitas yang berbeda dikonversi dulu menjadi nilai standar $\mathrm{Z}$, dan setelah itu nilai $\mathrm{Z}$ dari masing-masing kelas tersebut digabung menjadi satu.

Sebelum dilakukan analisis data menggunakan SEM, data yang diperoleh dari subjek penelitian diestimasi dulu validitas konvergen, validitas diskriminan, dan reliabilitas kompositnya. Factor loading empat butir yang mengukur motivasi belajar intrinsik berturut-turut adalah 0,69, 0,68, 0,71, dan 0,83. Untuk empat butir yang mengukur rehearsal loading factornya berturut-turut sebesar 0,46, 0,77, 0,77, dan 0,57. 
Selanjutnya loading factor empat butir yang mengukur elaborasi berturut-turut adalah $0,65,0,52,0,51$, dan 0,65; dan terakhir factor loading empat butir yang mengukur organisasi berturut-turut adalah 0,61,0,59,0,63, dan 0,64. Idealnya factor loading masing-masing butir yang mengukur konstrak latennya minimal adalah 0,70, sedangkan hasil yang diperoleh banyak yang lebih kecil dari 0,70. Akan tetapi semua butir tersebut tetap dapat dipakai untuk mengukur masing-masing kontraknya karena semuanya signifikan dan koefisiennya lebih besar dari 0,45 sebagai standar minimal.

Setelah semua butir yang mengukur masing-masing konstrak memiliki validitas konvergen, langkah selanjutnya adalah mengestimasi validitas diskriminan untuk masing-masing skala. Berdasar analisis faktor tahap pertama (first order) dengan menggunakan empat faktor, dalam hal ini faktor motivasi belajar intrinsik, faktor strategi belajar rehearsal, faktor strategi belajar elaborasi, dan faktor strategi belajar organisasi, diperoleh hasil sebagai berikut: 1) Nilai Average Variance Extracted (AVE) untuk skala motivasi belajar intrinsik sebesar 0,$350 ; \sqrt{ } 0,350=0,592$, lebih besar dari koefisien korelasi antara motivasi belajar intrinsik dengan strategi belajar rehearsal $(0,40)$, antara motivasi belajar intrinsik dengan strategi belajar elaborasi $(0,0,26)$, dan antara motivasi belajar intrinsik dengan strategi belajar organisasi $(0,40) ; 2)$ Nilai Average Variance Extracted (AVE) untuk skala strategi belajar rehearsal sebesar 0,$344 ; \sqrt{ } 0,344=0,587$, lebih besar dari koefisien korelasi antara strategi belajar rehearsal dengan motivasi belajar intrinsik $(0,40)$, antara strategi belajar rehearsal dengan strategi belajar elaborasi $(0,0,28)$, dan antara strategi belajar rehearsal dengan strategi belajar organisasi (0,32); 3) Nilai Average Variance Extracted (AVE) untuk skala strategi belajar elaborasi sebesar 0,424; $\sqrt{ } 0,424=0,651$, lebih besar dari koefisien korelasi antara strategi belajar elaborasi dengan motivasi belajar intrinsik $(0,40)$, antara strategi belajar elaborasi dengan strategi belajar rehearsal $(0,0,28)$, dan antara strategi belajar elaborasi dengan strategi belajar organisasi $(0,59)$. 4) Nilai Average Variance Extracted (AVE) untuk skala strategi belajar organisasi sebesar 0,377; $\sqrt{ } 0,377=0,614$, jauh lebih besar dari koefisien korelasi antara strategi belajar organisasi dengan motivasi belajar intrinsik $(0,40)$, antara strategi belajar organisasi dengan strategi belajar rehearsal $(0,32)$, dan antara strategi belajar organisasi dengan strategi belajar elaborasi $(0,59)$. Berdasar uraian di atas dapat disimpulkan bahwa keempat skala memenuhi validitas diskriminan karena AVE masing-masing lebih besar dari koefisien korelasi antara skala tersebut dengan tiga skala yang lain. Reliabilitas komposit (Composite Reliability) masing-masing skala adalah 0,795 (Motivasi), 0,878 (rehearsal), 0,825 (elaborasi), dan 0,818 (organisasi). Keempat skala Composite Reliability (CR)-nya lebih besar dari 0,7; berarti keempat skala memenuhi reliabilitas komposit.

Analisis data untuk menguji kedelapan hipotesis penelitian dilakukan dengan menggunakan Structural Equation Modeling (SEM) dengan bantuan perangkat lunak Analysis of Moment Structures (AMOS). Hasil analisis datanya ditampilkan pada Gambar 1. 


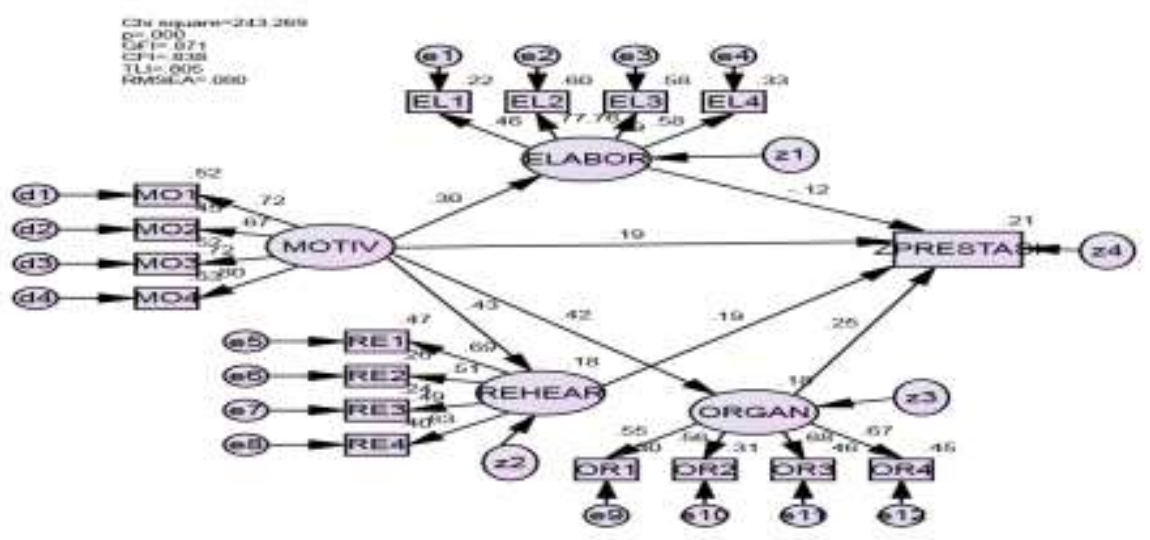

Gambar 1. Model penelitian awal

Berdasar Gambar 1 menunjukkan bahwa model tidak fit karena belum memenuhi kriteria kesesuaian seperti ditunjukkan pada Tabel 3.

Tabel 3.

Kesesuaian Model

\begin{tabular}{clll}
\hline Indeks Kesesuaian & Nilai kritis & Hasil Model & Evaluasi Model \\
\hline Chi square & Kecil & 243,269 & Tidak sesuai \\
P & $>0,05$ & 0 & Tidak sesuai \\
GFI & $>=0,90$ & 0,871 & Tidak sesuai \\
CFI & $>=0,90$ & 0,838 & Tidak sesuai \\
TLI & $>=0,90$ & 0,805 & Tidak sesuai \\
RMSEA & $<0,08$ & 0,080 & Tidak sesuai \\
\hline
\end{tabular}

Karena semua kriteria tidak fit, maka dilakukan modifikasi model dengan berpedoman pada Modification Indices (M.I.). Hasil revisinya ditampilkan pada Gambar 2.

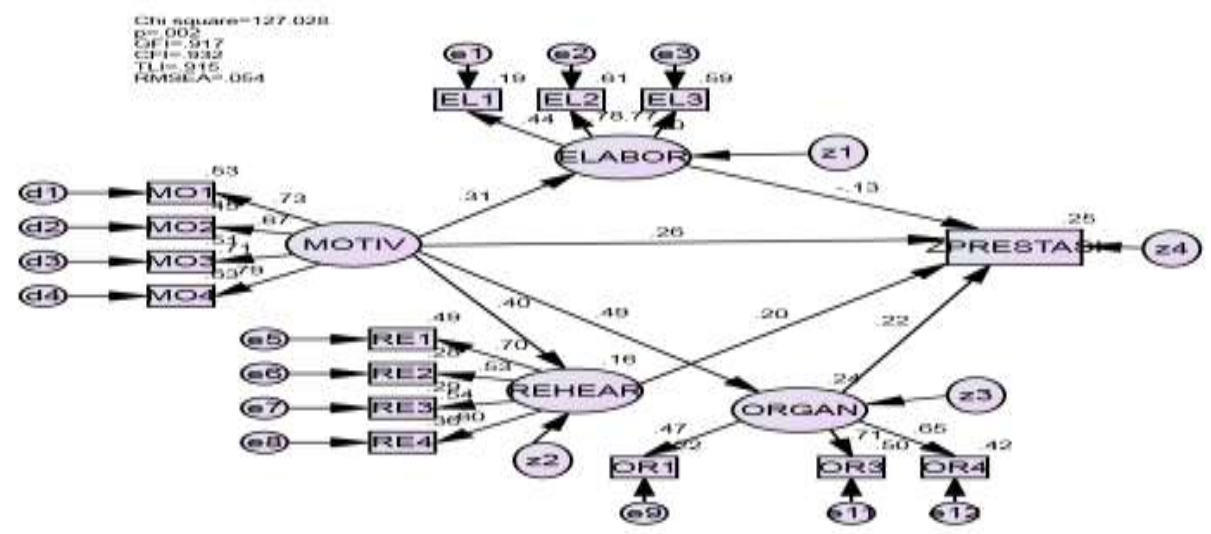

Gambar 2. Model penelitian hasil modifikasi 
Berdasar Gambar 2 menunjukkan bahwa kriteria kesesuaian model mengalami perubahan yang berarti dari sebelumnya, seperti ditunjukkan pada Tabel 4.

Tabel 4.

Kesesuaian Model (revisi)

\begin{tabular}{llll}
\hline Indeks kesesuaian & Nilai kritis & Hasil Model & Evaluasi Model \\
\hline Chi square & Kecil & 127,028 & Tidak Sesuai \\
P & $>0,05$ & 0,002 & Tidak Sesuai \\
GFI & $>=0,90$ & 0,917 & Sesuai \\
CFI & $>=0,90$ & 0,932 & Sesuai \\
TLI & $>=0,90$ & 0,915 & Sesuai \\
RMSEA & $<0,08$ & 0,054 & Sesuai \\
\hline
\end{tabular}

Model tidak sangat baik tapi sudah memadai untuk disimpulkan sebagai model yang fit. Dua dari enam indeks kesesuaian yang dipakai, yaitu chi-square dan $p$ menunjukkan model tidak sesuai (tidak fit).Langkah selanjutnya adalah mencek normalitas multivariat data penelitian. Ternyata normalitas multivariat dari kelima variabel penelitian tidak terpenuhi (critical ratio $=3,529$, lebih besar dari 2,58). Untuk tetap bisa melakukan estimasi hasil analisis yang dilakukan dengan metode Maximum Likelihood (yang mensyaratkan normalitas multivariat data), maka peneliti melakukan pengecekan melalui metode bootstrap. Dengan menggunakan 500 sampel bootstrap, diperoleh nilai $p$ Bollen-Stine sebesar 0,056, yang lebih besar dari 0,05 (tidak signifikan). Ini berarti hipotesis nihil yang mengatakan bahwa tidak ada perbedaan antara model teoretik dengan data tidak dapat ditolak. Dengan perkataan lain bahwa model diterima.

\section{Hasil}

Berdasar analisis data, hasilnya adalah sebagai berikut. Model teoretik yang menyatakan bahwa strategi belajar rehearsal, strategi belajar elaborasi, dan strategi belajar organisasi memediasi peran motivasi belajar intrinsik terhadap prestasi belajar statistika sesuai dengan data. Motivasi belajar intrinsik statistika memiliki peran positif langsung terhadap strategi rehearsal $(\lambda=0,400 ; p<0,01)$. Motivasi belajar intrinsik statistika memiliki peran positif langsung terhadap strategi elaborasi $(\lambda=0,309, p<0,01)$. Motivasi belajar intrinsik statistika memiliki peran positif langsung terhadap strategi organisasi $(\lambda=0,486$; $p<0,01)$. Strategi belajar rehearsal memiliki peran positif langsung terhadap prestasi belajar statistika $(\lambda=0,201 ; p<0,05)$. Strategi belajar elaborasi tidak berperan terhadap prestasi belajar statistika $(r=-0,129 ; p>0,05)$. Strategi belajar organisasi memiliki peran positif langsung terhadap prestasi belajar statistika $(\lambda=0,220 ; p<0,05)$. Motivasi belajar statistika 
memiliki peran positif langsung (direct effect) terhadap prestasi belajar statistika $(\lambda=0,259$ $(p<0,05)$, dan memiliki peran tidak langsung (indirect effects) sebesar $\lambda=0,147$ terhadap prestasi belajar statistika. Jadi efek total motivasi belajar intrinsik terhadap prestasi belajar statistika sebesar 0,406. Berdasar butir 8 berarti strategi belajar kognitif (rehearsal, elaborasi, dan organisasi) tidak berfungsi sebagai mediator atas peran motivasi belajar instrik terhadap prestasi belajar statistika; karena pengaruh langsung motivasi belajar intrinsik terhadap prestasi belajar matematika $(\lambda=0,259)$ lebih besar dari pengaruh tidak langsungnya $(\lambda=0,147)$

\section{Diskusi}

Hasil uji model menunjukkan data empiris yang diperoleh sesuai (fit) dengan model teoretik; sehingga selanjutnya dapat dilakukan pengujian hipotesis penelitian. Hasil uji hipotesis menunjukkan bahwa strategi belajar kognitif tidak memediasi peran motivasi belajar intrinsik terhadap prestasi belajar statistika. Peran langsung motivasi belajar intrinsik terhadap prestasi belajar statistika $(0,259)$ lebih besar daripada peran tidak langsungnya $(0,147)$. Hal ini bisa terjadi karena salah satu strategi belajar kognitif, yaitu strategi belajar elaborasi ditemukan tidak berperan terhadap prestasi belajar statistika. Hipotesis penelitian yang berbunyi strategi belajar elaborasi berperan positif terhadap prestasi belajar statistik ternyata ditolak kebenarannya. Ditolaknya hipotesis tersebut kemungkinan berkaitan dengan sifat ujian mata kuliah statistika yang opened book dan tidak banyak menanyakan konsep melainkan ketepatan menggunakan teknik dan rumus statistik untuk dapat menjawab soal. Selain itu strategi seperti "belajar dari sumber lain", mungkin jarang dilakukan oleh mahasiswa, karena mereka merasa sudah cukup dengan mempelajari materi statistika yang diberikan oleh dosen di kelas. Demikian juga dengan "sebelum mengikuti kuliah statistika menyiapkan diri menguasai materi yang mendasari" jarang dilakukan oleh mahasiswa, terkecuali metode pembelajaran statistika yang dipakai adalah diskusi kelompok, atau dosen selalu menanyakan materi kuliah sebelumnya saat akan memulai kuliah. Butir "menghafal konsep dengan menggunakan kata-kata sendiri" kemungkinan juga jarang dilakukan oleh mahasiswa karena bentuk ujian matematika bukan fokus pada pemahaman konsep tapi langsung praktik menghitung.

Dalam proses analisis data untuk menguji kesesuaian model teoretis dengan data yang diperoleh, dilakukan dua tahap. Hasil uji model tahap pertama model tidak fit; semua indeks kesesuaian belum memenuhi nilai kritis. Berdasar indeks modifikasi, peneliti menghilangkan butir nomor 4 dari skala elaborasi dan butir nomor 3 dari skala organisasi. Butir nomor 4 elaborasi berbunyi "Untuk memahami konsep dan teori dalam statistika, saya menghafalkannya dengan menggunakan kata-kata sendiri". Butir nomor 2 organisasi berbunyi "Saya membuat catatan tentang garis besar dari materi pelajaran statistika yang saya pelajari untuk mempermudah memahaminya". Menghilangkan satu butir elaborasi dan satu butir organisasi tersebut tidak mengurangi validitas konstruk secara berarti 
mengingat tiga butir lainnya dalam masing-masing variabel masih mewakili konstruk kedua variabel.

Setelah dua butir dihilangkan selanjutnya dilakukan analisis ulang, dan hasilnya model dinyatakan memadai (fit). Berdasar enam indeks kesesuaian, empat indeks kesesuaian sudah menunjukkan bahwa model fit. Dua indeks kesesuaian, yaitu chi-square dan $\mathrm{p}$ menunjukkan bahwa model tidak sesuai (tidak fit). Hal ini bisa disebabkan karena distribusi skor variabel-variabel penelitiannya tidak memenuhi normalitas multivariat. Namun demikian hasil analisis yang sudah dilakukan menggunakan Maximum Likelihood masih dapat dipertanggungjawabkan untuk mengestimasi parameter karena setelah dicek dengan metode bootstrap dengan menggunakan sebanyak 500 sampel bootstrap (Mean = 94,783, Standar kesalahan $=0,833$, penyebaran skor ke kanan dan ke kiri kurva poligon seimbang), ditemukan nilai $p$ Bollen-Steine sebesar 0,056, lebih besar dari 0,05 (tidak signifikan). Ini berarti hipotesis nihil yang menyatakan bahwa tidak ada perbedaan antara model teoretis dengan data tidak dapat ditolak; atau dengan perkataan lain model diterima.

\section{Kesimpulan}

Berdasar hasil analisis data dan pembahasan, penelitian ini menyimpulkan. 1) Model teoretis peran motivasi belajar intrinsik terhadap prestasi belajar statistika dengan mediator strategi belajar kognitif cocok atau sesuai dengan data. 2) Variabel motivasi belajar intrinsik, strategi belajar rehearsal, dan strategi belajar organisasi berperan positif terhadap prestasi belajar statistika, sedangkan strategi belajar elaborasi tidak berperan terhadap prestasi belajar statistika. 3) Strategi belajar kognitif, yang meliputi strategi belajar rehearsal, strategi belajar elaborasi, dan strategi belajar organisasi, tidak berfungsi sebagai mediator atas peran motivasi belajar intrinsik terhadap prestasi belajar statistika.

\section{Saran}

Peneliti selanjutnya dapat melakukan analisis terhadap mediator selain strategi belajar kognitif terkait dengan hubungan antara motivasi belajar dengan prestasi belajar. Selain itu, di dalam penelitian ini, subjek sangat homogen. Variasi subjek kemungkinan dapat membantu membuat data penelitian menjadi lebih kaya.

\section{Kepustakaan}

Akyol, G., Sungur, S., \& Tekkaya, C. (2010). The contribution of cognitive and metacognitive strategy use to students' science achievement. Journal Educational Research and Evaluation An International Journal on Theory and Practice. 16(1), 1-21. https://doi.org/10.1080/13803611003672348 
Amrai, K., Motlagh, S. E., Zalani, H. A., \& Parhon, H. (2011). The relationship between academic motivation and academic achievement students. Procedia Social and Behavioral Sciences, 15, 399-402.

Anais, M. J., Hojas, A. M., Bustos, A., Letelier. C., Zuzulich, M. S., Cabieses, B., \& Zubiaguirre, M. (2012). Motivational and cognitive learning strategies used by firstyear engineering undergraduate students at Universidad Católica in Chile, 3, Special Issue, 811-817. Published Online October 2012 in SciRes (http://www.SciRP.org/journal/ce)

Bandalos, D .L., Finney, S. A., \& Geske, J. A. (2003). A model of statistics performance based on achievement goal theory. Journal of Educational Psychology, 95(3), 604-616. https://doi.org/10.1037/0022-0663.95.3.604

Chin, C. \& Chin, L. (2009). Cognitive strategies. (http://www.education.com/reference/ article/cognitive-strategies/)

Chow, S. J., \& Yong, B. C. S. (2013). Secondary school students' motivation and achievement in combined science. US-China Education Review B, 3(4), 213-228

Chung, Mi-Kyung. (2000). The development of self-regulated learning. Asia Pacific Education Review. 1, 55-66. ( $\quad$ http://www.aped.snu.ac.kr/prof/ aper/aper\%20data/1-106-Mi Kyung\%20Chung.pdf)

De Boer, H., Donker-Bergstra, A. S. \& Kostons, D. D. N. M. (2012). Effective strategies for self- regulated learning: A meta-analysis. Gronings Instituut voor Onderzoek van Onderwijs, Rijksuniversiteit Groningen. (https://www.nro.nl/wpcontent/uploads/2014/05/PROO_ Effective+ strategies+for+selfregulated+learning.pdf

Lee, In-Sook. (2002). Gender differences in self-regulated on-line learning strategies within Korea's University Context. International Review, ETR \& D, 50(1), 101-102.

Meniado, J. C. (2016). Metacognitive reading strategies, motivation, and reading comprehension performance of Saudi EFL Students. English Language Teaching; 9(3). https://doi.org/10.5539/elt.v9n3p117

Muhammad, A. S., Bakar, N. A., Mijinyawa, S. I., \& Halabi, K. A. (2013). Impact of motivation students' academic performance: A case study of University Sultan Zainal Abidin Students. The American Journal of Innovative Research and Applied Sciences. (www.american-jiras.com).

Murayama, K., \& Pekrun, R. (2012). Predicting long-term growth in students mathematics achievement: The unique contributions of motivation and cognitive strategies. Child Development, $\quad$ 1-16. $\quad$ http://scottbarrykaufman.com/wpcontent/uploads/2012/12/Murayama-et-al 2012 CD.pdf.

Ormrod, J. E. (2003). Educational psychology: developing learners, $4^{\text {th }}$ edition. Merrill Prentice Hall.

Parson, R. D., Hinson, S. L., \& Sardo-Brown, D.(2001). Educational psychology. Apractitionerresearcer model of teaching. Thomson Learning, Inc. 
Pintrich, P. R. \& De Groot, E. V. (1990). Motivational and self-regulated learning components of classroom academic performance. Journal of Educational Psychology, 82, 33-40. https://doi.org/10.1037/0022-0663.82.1.33

Ruffing, S., F., Wach, S., Spinath, F. M., Brünken, R., \& Karbach, J. (2013).Learning strategies and general cognitive ability as predictors of gender- specific academic achievement. (http://www.ncbi.nlm.nih.gov/pmc/articles/PMC4541601/)

Schmidt, R., \& Watanabe, Y. (2001). Motivation, strategy use, and pedagogical preferences in foreign language learning. (Dalam Z. Dörnyei \& R. Schmidt (Eds.), Motivation and second language acquisition (Technical Report \#23, pp. 313-359).

Slavin, R. E. (2012). Educational Psychology. Third edition. Prentice-Hall, Inc.

Tinajero, C., Lemos, S. M., Araújo, M., Ferraces, M. J., Páramo, M. F. (2015). Cognitive style and learning strategies as factors which affect academic achievement of brazilian university students. Psicol. Reflex. Crit. 25(1). http://dx.doi.org/10.1590/S0102-79722012000100013

Wolters, C. A. (1998). Self-regulated learning and college students' regulation of motivation. Journal of Educational Psychology, 90, 224-235. https://doi.org/10.1037/0022-0663.90.2.224

Wolters, C.A., Pintrich, P. R., \& Karabenick, S. A. (2003). Assessing academic selfregulated learning. Paper prepared for the conference on indicators of positive development. Sponsored by Child Trends, National Intitutes of Health. www.childtrends.com/meeting_schedule/pdf/woltersfinal.pdf

Zimmerman, B. J. \& Martinez-Pons, M. (1990). Student differences in self-regulated learning:Relating grade, sex, and giftedness to self-efficacy and strategy use. Journal of EducationalPsychology, 82, 51-59. https://doi.org/10.1037/0022-0663.82.1.51 